PETTIGREW, R., DRISCOLL, C. J., AND RIENITs, k. G. 1969. A spontaneous chlorophyll mutant in hexaploid wheat. Heredity, 24, 481-487.

SEARs, E. R. 1953. Nullisomic analysis in common wheat. The American Naturalist, Vol. LXXXVII, No. 835, 245-252.

SEARs, E. R. 1959. Neatby's virescent. Genetics, 44, 534.

SEARs, L. M. 8., AND sEARs, E. R. 1968. The mutants Chlorina-1 and Hermsen's virescent. Proc. 3rd Int. Wheat Genetics Symp., 299-304.

\title{
TWIN BIOLOGY
}

\author{
C. D. DARLINGTON \\ School of Botany, University of Oxford
}

Received 18.v.70

TwinNING concerns anyone who may want to study plant or animal reproduction. Whether his concern is anatomical, physiological or genetical, its causes and its consequences need to be weighed and judged. The more we have learnt, however, of these relations, the more complicated they have seemed to become. So much so that experts have learnt to shrink reluctantly from probing them to their genetic depths.

TABLE 1

Frequencies of embryologically classified types of twins in European populations (after Bulmer, 1970, and J. H. Edwards, 1968)

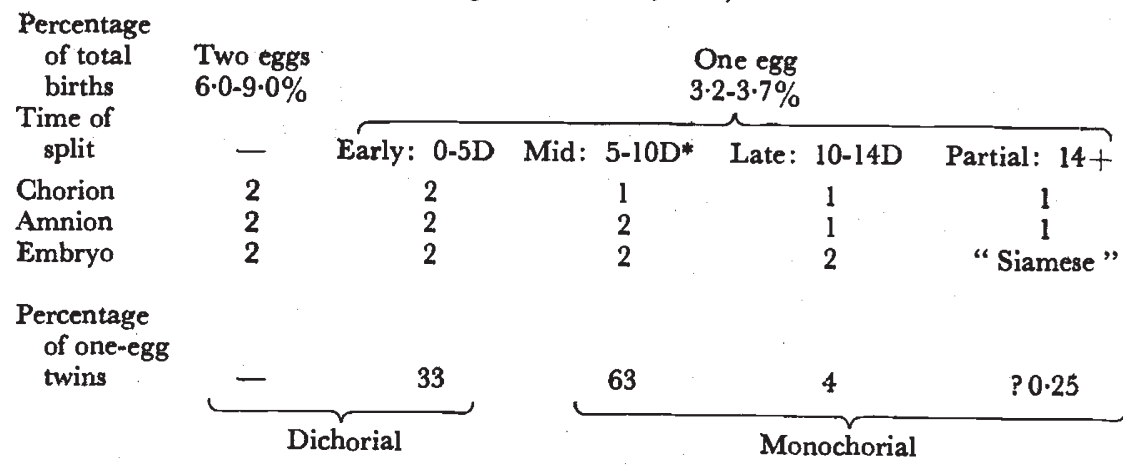

* Between implantation at 5 days and differentiation of the amnion at 10 days.

Dr Bulmer, the most recent investigator, despite his title, shares this reluctance. Still others may share it when faced with his diagram of crossing over (fig. 1.2). Nevertheless, for anyone who wants to go further, by his careful statistical treatment he clears the ground and uncovers some if not all of the pitfalls. It is worth our while therefore to take this opportunity of seeing what the ground looks like today.

Certain principles are clear from the surveys made by Bulmer and earlier by Edwards (table 1). The frequency of one-egg twins can be established only by genetic tests of identity since early splitting gives chorions and amnions as separate as in two eggs twins. The mode of origin therefore has to be deduced from the identity and not the identity from the mode of origin. These tests however are now certain and varied enough to leave little room for error. They allow us to say, on the one hand, that one-egg 
twins are almost invariable in frequency throughout the human species. Two-egg twins, on the other hand, vary in frequency between 2.5 per cent. among Japanese and 40 per cent. among Yoruba. Even in Europe and in one European country, France, the frequency varies regionally from 6 per cent. to 9 per cent. These differences are not only regional, they are familial, racial, and genetic. And they are independent of the other wellestablished sources of variation, the age and nutrition of the mother.

In addition to these statistically ascertainable properties of twins there are others which are more difficult to record. The formation of a joint placenta owing to close implantation of the two embryos is presumably more frequent for one-egg than for two-egg twins. It entails the occasional hazard of transfusion or joint circulation with the danger of blood chimaerism for two-egg twins and the quite different danger of unequal, or even what we may call parasitic, circulation for both types. A third danger of twisted cords arises only with one-egg twins. All these hazards contribute to the disadvantages in foetal growth of twins of both kinds and they most obviously contribute in one-egg twins to the inequalities of birthweight which in extreme cases affect all later development, mental as well as physical.

These questions, which are discussed by Bulmer, raise others which concern the use of twins in estimating the relative effects of heredity and environment. We recognise today that "heredity" is conditional on the breeding system and "environment" on the social system and both vary with the heterogeneity of the population. These reservations, are the first to remember in using a distinction which is vital for understanding the chief genetic problems of society. But, in addition, it has long been clear that environment has a special meaning for one-egg twins since what is external to each is internal to the two. For one-egg twins there are therefore sources of discordance which are neither genetic nor environmental in the ordinary sense. And they can now be individually distinguished. These may be provisionally classified as follows:

1. Nuclear differences: arising by gene mutation or chromosome loss or gain in one of the two products of splitting (Bruins, 1963; Dekaban, 1966; Edwards et al., 1966).

2. Cytoplasmic differences: arising by the actions of deleterious genes in an asymmetrical cytoplasm (Darlington, 1954).

3. Embryological differences: arising from errors of late splitting (Liebenam, 1938).

4. Nutritional differences: arising from the errors of joint placentation (Price, 1950; Uchida et al., 1957).

A number of lines of inquiry arise from this classification. For example in the Edwards' twins the plane of splitting between the twins does not follow the cell-lineage divisions as shown either by the chromosomes or by the sexual character which they determine. Each twin is therefore a mosaic, a sexual mosaic, just as he is when cells migrate through the placenta between two-egg twins. Again in the remarkable case described by Walker (1950) where two one-egg twins have two different abnormalities, the one retinoblastoma, the other cleft palate, we have the opposite possibility that a reciprocal chromosome difference due to bridge-breakage at mitosis is directly responsible; the difference between the twins is then precisely a cell-lineage difference. 
There is another problem discussed by Bulmer, that of mirror imaging, which deserves to be kept in mind. If we agree that left-handedness and situs inversus of the viscera occur no more frequently than by chance in oneegg twins there remains the question of whether we assign the difference to heredity or to environment. Surely to neither. It is the effect of an uncertainty in development. It resembles that primary uncertainty in the position of partner chromosomes at meiosis which underlies the almost universal uncertainty in frequency of crossing-over. But it differs inasmuch as it seems to lie close to the limit of selectable variation.

When all these questions have been considered we may return to ask ourselves where we stand with the classical assumption that one-egg twins are genetically identical and their discordances assignable to the " environment". It seems we have to withdraw this assumption and replace it with the principle that their discordance gives us a maximum estimate, and statistically always an over-estimate of environmental influence. If we are to assess the value of such tests as those of intelligence or of susceptibility to tuberculosis which are quoted by Bulmer, this, I suggest, is what matters most.

\section{REFERENGES}

BRuins, J. w. 1963. Discordant mongolism in monozygotic twins. Proc. 11 Int. Congr. Genet., 1,307 .

BULmer, M. G. 1970. The Biology of Twinning in Man. Clarendon Press, Oxford.

DARLINoton, C. D. 1954. Heredity and environment. Caryologia, Supplement to Vol. VI, 370-381.

DARLINGton, C. D. 1969. Mosaics, twins and inter sexes. Nature, 223, 328-329.

DEKABAN, A. 1966. Twins, probably monozygotic: one mongoloid with 48 chromosomes, the other normal. Cytogenetics, 4, 227-239.

EDWARds, J. H. 1968. The value of twins in genetic studies. Proc. R. Soc. Med., 61.

EDWARDs, J. H., et al. 1966. Monozygotic twins of different sex. F. Med. Genet., 3, 77-158. LIEBENAM, t. 1938. Zwillingspathologische untersuchungen u.s.w. Z. mensch. Vererb. u. Konstl., 22, 373-417.

PRICE, BRONSON. 1950. Primary biases in twin studies: are view of prenatal and natal difference-producing factors in monozygotic pairs. Am. F. Hum. Genet., 2, 293-352.

RIFE, D. C. 1952. Twins and research. Acta Genet. Med. Gemell., 1, 14-23.

STERN, C. 1968. Genetic Mosaics and Other Essays. Harvard U.P., Cambridge, Mass; Oxford U.P., London.

UCHIDA, I. A., AND ROWE, R. D. 1957. Discordant heart anomalies in (one-egg) twins. Am. $\mathcal{F}$. Hum. Genet., 9, 133-140.

WALKER, N. F. 1950. Discordant monozygotic twins (A) with retinoblastoma and (B) cleft palate. Am. F. Hum. Genet., 2, 375-384.

\section{STUDIES ON THE RNA OF THE MATE-KILLER PARTICLES OF PARAMECIUM}

RAY BAKER

School of Biological Sciences, University of East Anglia, Norwich

Received 27.v.70

\section{Introduction}

KILLeR particles were discovered originally as cytoplasmically inherited factors responsible for the killing activity of certain stocks of Paramecium aurelia (Sonneborn, 1943). They were shown to require the presence of a 